\title{
Contribution of Environment Behaviors and Interpersonal Behaviors oward Job Readiness Industrial Work Practices
}

\author{
Dina Kamaliya \\ Faculty of Teaching and Education \\ Universitas Lambung Mangkurat \\ Banjarmasin, Indonesia \\ dinakamaliya@gmail.com
}

\author{
Dwi Atmono, Sri Setiti \\ Faculty of Teaching and Education \\ Universitas Lambung Mangkurat \\ Banjarmasin, Indonesia
}

\begin{abstract}
Social Studies play an important role in social skills learning. Social Studies play an important role in the formation of social skills. Social skills are the ability of individuals to interact both verbally and non verbally in order to adapt and be accepted by the environment obtained through the learning process. Environment behaviors or attitudes of students to the environment are still in the medium category. It shows that students still need to be familiarized in their sensitivity to the environment, and it needs to be considered again in the indicators of Care for the Environment and Movement around the Environment. Environment behaviors and Interpersonal behaviors have a high contribution to the readiness of work on industrial work practices
\end{abstract}

Keywords- Social Studies, Environment behaviors, Interpersonal.

\section{INTRODUCTION}

Vocational High School is expected to prepare the graduates to be ready to achieve career success wherever they work. Social Studies play an important role in social skills learning. Students are taught to be active in learning, discovering, communicating their findings in front of a classroom where it can foster self-confidence, independence, compete, communicate, work with peers, solve problems, and make decisions.

The Implementation of Industrial Work Practices in Vocational High School Education is based on Kepmendikbud No. 080 / U / 1993 Chapter IV outlined the mutually beneficial principle that cooperation between Vocational High School and the business and the industrial work, carried out with the principle of mutual help, complementary, implementation of education with Industrial Work Practices will benefit to both.

Social skills are the ability of individuals to interact both verbally and non verbally in order to adapt and be accepted by the environment obtained through the learning process. Social skills that need to be owned by [1] namely "Living and working together; taking turns; respecting the right of others; being socially independent, sharing self-control and selfdirection, sharing ideas and experience with others. "Social skills include behavior toward the environmental behavior, interpersonal behavior, self-related behavior, and task-related behavior. This research focused on environmental behaviors and interpersonal behaviors because these two skills were directly related to how do the students' attitudes in their environment and how do students build relationships with peers, people in their neighborhood or teachers at school.

Green behavior among them is that there is a good action to be done, the habits or behaviors of the students towards the environment not only in the case of throw the trash in place, but also in many other ways. Such as saving electricity by turning off the lights, not letting the computer turn on after not being used, letting the water continue to flow, the fan and LCD projector is shut down when it is no longer in use.

Interpersonal behavior is a form of behavior that shows the social behavior of individuals in knowing and holding relationships with other individuals (with peers or teachers). Form of social behavior is associated with others, both peers and teachers. According to [2], education basically has two goals, namely to guide the younger generation to be smart and to have virtuous behavior. Problems that arise related to the development of social behavior are unattached peers in the peers group easily lead to juvenile delinquency, fights, theft, conflict with parents, feeling not happy at home even escape from home, doing acts that contradict the norms of society, use drugs and so on.

\section{DISCUSSION}

\section{A. Social Skills In Social Studies}

Social Studies play an important role in the formation of social skills. National Council for Social Studies or [3] 
proposes several powerful learning principles: meaningful, integrative, value-based, challenging, and active.

\section{B. Environment Behaviors in Social Studies}

Social Studies can be grouped into four categories: Knowledge, Skill, Attitude, and Value. Knowledge, which is the main goal of Social Studies, is to help students learn about themselves and their environment. Skills, is related to Social Studies goals, in this case including thinking skills. Attitude, grouped into two, the group of attitudes needed for behavior thinking and social behavior. Value, in this connection is the value contained in the surrounding community obtained from the surrounding community and government agencies. People who do not obey norms may not apply those norms to others. [4]. How important environmental sustainability for the preservation of human life and other living things is found in the following Earth Charter. Ref [5] who argued that:

a. Provide all, especially children and youth, with educational opportunities that empower them to contribute actively to sustainable development.

a. Promote the contribution of the arts and humanities as well as the Studies in sustainability education.

b. Enhance the role of the mass media in raising awareness of ecological and social challenges.

c. Recognize the importance of moral and spiritual education for sustainable living.

Green Behavior is one term that is widely used to reflect behavior that describes the habits that need to be formed to foster love for the environment. Green behavior in Social Studies can be applied through ecopedagogy as an instruments of learning as an approach and learning process to form students' knowledge, attitudes, traits and skills that are aligned with the green living movement. In the Local wisdom of Banjarese, there are terms related to preserving the environment such as "awak sihat wan barasih, hidup nyaman, mati baiman ", which means that if the body is healthy and accustomed to clean, then life will be comfortable, and achieve death as a believer.

\section{Interpersonal Behaviors in Social Studies}

Interpersonal behaviors is the social behavior of individuals in knowing and holding relationships with other individuals (with peers or teachers). Ref [6] defines peers as others who are equal to themselves and who do not impose sanctions of the adult, and also provide a place to socialize with the values imposed by his age. Ref [7] states that peers are children or adolescents who have the same age or maturity level. Peer environment is a new group, which has characteristics, norms, habits that are very different from what is in the family environment.

Ref [8] explains that socialization is a process in which individuals train their sensitivity to social stimuli, especially the pressures and demands of life (group); learning to behave like other people in his sociocultural environment. This includes such social interactions, prosocial, empathy, social participation and social ability in peers. Major categories of social skills (CCAREES): Communication, Cooperation,
Assistance, Responsibility, Empathy, Engagement, and Self Control [9]. Ii includes social interaction, prosocial, empathy, social participation and social ability in peers. Top social skills in the school environment are listens to others, follow directions, follow classroom rules, ignore peer distraction, ask for help, takes turns in conversations, cooperate with others, controls kindness to others [9]. Interpersonal behaviors in the school environment with friends are able to complete the task together, and the results achieved will be perceived kindness by all members.

The appropriate application and interpretation of verbal and non verbal communication signals, such as eye contact, posture, social distance, facial expressions and speech tone are essential for a person to be effective in interpersonal relationships [10]. Self-control is where learners learn to stop and think before reacting, considering the solutions and consequences of different responses and keep a cool head [11]. Interpersonal behaviors in the school environment with friends are able to complete the task together and the results achieved will be perceived good by all members.

Interpersonal behaviors according to Stephens in [10] consist of Accepting Authority, Coping with Conflict, Gaining Attention, Greeting Others, Helping Others, Making Conversation, Organized Play, Positive Attitude toward others, Playing Informally and Property: Own and Others. Attitude is a readiness for a person to act in a certain way towards certain things. A positive attitude from within an individual about a job or career will affect the individual's readiness to do a job. The term Banjar, it is "Badiri Sadang, Baduduk Sadang" which means standing right, sitting also appropriate or recommended to be good at carrying wherever they are.

\section{B. Job Readiness on Industrial Work Practices}

A person's skill affects readiness to do a job. Readiness is the level of development of maturity or maturity that is profitable to practice something. According to the US department of labor, it consists of: (a) a participant as a team member, (b) a job or task training, (c) exhibiting good manner d) completed a job or task (e) follow procedures, (f) maintains a positive attitude, ( $\mathrm{g}$ ) is responsible for his/ her actions, (h) is punctual and reliable in attendance, (i) holds good relationships with co -workers, (j) copes with stressful simulations. Ref [12] suggested 6 benefits of having social skills for individuals, namely:

a. The development of Personality and Identity

b. The development of Work Capacity, Productivity, and Career Success

c. The improvement of Quality of Life

d. The improvement of Physical Health

e. The improvement of Psychological Health

f. The ability to Overcome Stress

Industrial Work Practice is part of Double System Education as a joint program of Vocational High School and industry related to the concept of link and match that is executed from business and industrial work to prepare students who are ready to work as their graduates targets. Directing students directly to the practice aims to enable 
students to directly apply their knowledge and competency skills in accordance with their majors.

\section{Contribution Of Environment Behaviors And Interpersonal Behaviors To Job Readiness On Industrial Work Practices}

The variables measured in this study are the variables of environment behaviors and interpersonal behaviors adapted from the book [13] titled Teaching Social Skills to Children and Youth Innovative Approach and [14]. Social Skills in the Classroom. Job readiness adapted from [15] entitled Revised Handbook for Analyzing and using assessment in the assessment results by the mentors of the business and the industrial work contained in daily journals. Writer used descriptive analysis with the Statistical book from [16] therefore I can obtain the right and factual information about The Contribution of Environment Behaviors and Interpersonal Behaviors in the Social Studies on the Job Readiness of Industrial Work Practices.

TABLE 1. INVENTORIES OF ENVIRONMENTAL BEHAVIORS AND INTERPERSONAL BEHAVIORS THAT CAN BE DEVELOPED IN SOCIAL STUDIES

\begin{tabular}{|c|l|}
\hline Environmental Behaviors & \multicolumn{1}{|c|}{ Interpersonal Behaviors } \\
\hline & Accepting Authority (AA) \\
& Coping with Conflict (CC) \\
Care for the Environment (CE) & Gaining Attention (GA) \\
Dealing with Emergencies (DE) & Greeting Others (GO) \\
Lunchroom Behaviors (LB) & Helping Others (HO) \\
Movement around Environment & Making Conversation (MC) \\
(MO) & Organized Play (OP) \\
& Positive Attitude toward others (PA) \\
& Playing Informally (PI) \\
& Property: Own and others (PO) \\
\hline
\end{tabular}

Source: [14]

\section{TABLE 2. INVENTORIES OF JOB READINESS}

\begin{tabular}{|c|ll|}
\hline & 1. & $\begin{array}{l}\text { Logical and objective considerations } \\
\text { Ability and willingness to cooperate with } \\
\text { others }\end{array}$ \\
& Job Readiness & $\begin{array}{l}\text { Critical attitude } \\
\text { 4. }\end{array}$ \\
& Courage accepts responsibility & Ability to adapt to the environment \\
6. & Ambition to move forward and try \\
\hline
\end{tabular}

Source: [15]

The results shows that 1) the contribution of the concept environment consisted of $\mathrm{CE}, \mathrm{DE}, \mathrm{LB}$ and $\mathrm{MO}$ of $60 \%$ in the medium level; 2) the interpersonal contribution of the concept consisted of AA, CC, GA, GO, HO, MC and PA at $73 \%$; and 3) the contribution of concept and interpersonal concept environment in the readiness of industrial work practice of $68 \%$ in high level.

It requires the development of application of environment behaviors in learning because basically education has two goals, namely to guide the younger generation to be smart and have virtuous behavior. Therefore, an education can not be said to succeed if the learning is only focused on academic intelligence, but must develop good morality, one of them by providing learning that develop environmental awareness.In addition, interpersonal behaviors also need better habituation despite being included in the high category, students need to get used to responsible in everything that is entrusted to him and able to avoid conflicts that occur especially in the environment of peers."

\section{CONCLUSION}

1. Environment behaviors or attitudes of students to the environment are still in the medium category. It shows that students still need to be familiarized in their sensitivity to the environment, and it needs to be considered again in the indicators of Care for the Environment and Movement around the Environment.

2. Interpersonal behaviors fall into the high category, which means that students build relationships with others, especially peers and teachers well. There is no such big problem, but it should be noted in the indicators of Accepting Authority and Coping With Conflict.

3. Environment behaviors and Interpersonal behaviors have a high contribution to the readiness of work on industrial work practices. Therefore, the students need to develop more social skills by applying the five principles powerful of Social Studies namely meaningful learning, integrative, value-based, challenging and active in order to be able to compete in the business and industry work.

\section{REFERENCES}

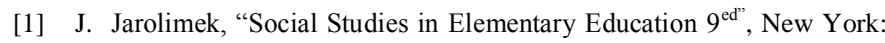
Macmillan Publishing Co. Ltd, 1993.

[2] T. Lickona, , "Education for Character", Jakarta: Bumi Aksara, 2013.

[3] NCSS, "Curriculum Standard for Social Studies: Expectation of Excellence", Washington, DC,: NCSS, 1994.

[4] J. S. Coleman, Foundation of Social Theory, Cambridge: Harvard University, 2010

[5] UNESCO, Earth Charter, http://www.earthcharter.org.au, 2007.

[6] E. B. Hurlock, "Developmental Psychology", McGraw-Hill Education, 2001.

[7] J. W. Santrock, "Remaja $11^{\text {ed" }}$ Alih Bahasa: Benedictine Widyasinta, Jakarta: Erlangga, 2007.

[8] M. R. Loree, "Psychology of Education", New York: The Ronald Press, 1970.

[9] S. N. Elliot, "Social Skills Development in Early Childhood", Arizona State University, www.psychcorp.com, 2002.

[10] A. Zsolnai, "Functioning of Social Skills from Middle Childhood early Adolescence in Hungary", Vol. 6, Number 2, November 2014, University of Szeged, Hungary, 2014.

[11] D. Goleman, "Social Intelligence, The New Studies of Human Relationship", Jakarta: PT. Gramedia, 2007.

[12] D. W. Johnson \& F. P. Johnson, "Joining Together: Group Theory and Group Skill", Pearson Education Company: New York, 2000.

[13] G. Cartledge \& J. F. Millburn, "Teaching Social Skills to Children \& Youth Innovative Approach", 3rd ed, New York: Pergamon Press, 1995.

[14] T. Stephens, "Social Skills in the Classroom, Psychological Assessment Resources", Inc. Odesa, 1992.

[15] U.S. Department of Labor, "Revised Handbook for Analyzing Jobs", Washington DC: US Department of Labor, 1991.

[16] D.R. Anderson, et al, "Statistic for Bussiness and Economics", Ohio: Book Masters, 2001. 